\title{
The Poetics of Foregrounding: The Lexical Deviation in Ulysses
}

\author{
Xianyou $\mathrm{Wu}$ \\ Chongqing Normal University, Chongqing, China \\ Email:wuxyou@yahoo.com.cn
}

\begin{abstract}
In Ulysses, there is a whole repertoire of linguistic inventiveness, creativity and play in the form of new words and odd constructions, which calls for our close reading. Lexical Inventiveness, as I argue, best characterizes Joyce's lexical revolution in which both creativity and playfulness of language are fully stressed. To have a better understanding of them, this chapter is to investigate special conversions, unusual compounds and comic word-play by means of classification and comparison. Our studies show: (1) Joyce's defamiliarized lexis is more motivated than arbitrary as he made the best use of the accepted lexical resources; (2) As for various word formations, we find that Joyce's verb conversion follows fairly well the word-formation rules, his compounds deviate a lot from the rules and his jumbled compounds are, in its true sense, what Bakhtin calls "linguistic carnivalization"; (3) Semantically, neologisms, though fleeting, are terse, lively, exciting, expressive, and above all true to life. (4) Perfect truth was perfect language." (French, 1982). The point with his linguistic inventiveness is to make full use of the visual and auditory textures of words, including their musical nature, and to increase the expressive power of literary language, and thus to achieve the special artistic effects of "defamiliarization" by increasing the difficulty of reading and lengthening their time of perception, and it is in grappling with linguistic deviation, creativity and indeterminateness that lies much of the pleasure of reading Ulysses. So Joyce's linguistic inventiveness is part of his artistic ingenuity in fiction and calls for further studies.
\end{abstract}

Index Terms - foregrounding, lexical deviation, stylistic effects, Ulysses

\section{INTRODUCTION}

In Ulysses, there is a whole repertoire of linguistic inventiveness, creativity and play in the form of new words and odd constructions, which calls for our close reading. Lexical inventiveness, as I argue, best characterizes Joyce's lexical revolution in which both creativity and playfulness of language are fully stressed. To have a better understanding of them, this paper is to investigate special conversions and unusual compounds by means of classification and comparison. By employing the theory of "defamiliarization", this article aims at a relatively systematic study on two kinds of word formation -- verb conversion and compounds, so as to demonstrate Joyce's rules of lexical inventiveness and their special stylistic values, and thus to help readers with a better understanding of Joyce's artistic use of the literary language.

"Defamiliarization", a key term for the Russian formalists in the 1920s, has greatly shaped the linguistic and literary ideas of the Russian Formalism, the New Critics and the French Structuralism, and it also plays an important role in narratology and stylistics. According to Shklovsky(1965), the function of art is to make people aware of the world in a fresh way and the device is "defamiliarization" or "making strange", "the technique of art is to make objects 'unfamiliar', to make forms difficult, to increase the difficulty and length of perception because the process of perception is an aesthetic end in itself and must be prolonged." He even believes that literariness resides in the defamiliarized language. In fact, some other scholars, such as Mukarosvsky(1964), Fowler(1996), van Peer(1986), Leech(2001), and others, strongly support this idea. So far, Shklovsky's theory of "defamiliarization" is by no means outmoded, and moreover, it is often lauded as a guiding principle and an effective literary approach both in literary criticism and stylistics.

\section{SPECIAL CONVERSION}

Conversion is generally defined as a word-formation process whereby a word of a certain word class is shifted into another class without the addition of an affix, or more scientifically termed as "derivation by zero suffix". Converted words do not technically add new words to the lexicon of English, but they can extend the semantic range of existing words by changing their grammatical functions. Conversions can be grouped into various kinds, such as Noun $\rightarrow$ Verb, Verb $\rightarrow$ Noun, Adjective $\rightarrow$ Verb, Adjective $\rightarrow$ Noun, and so on. Since almost all kinds of conversion can be found in Ulysses, the corpus would be too large for us to control. For convenience, I shall restrict my scope of research to two types of conversion: verb and non-verb conversions. The former refers to all those converted verbs (including verb-ing and verb-ed) from other word classes while the latter is a miscellaneous group consisting of all the converted words but verbs. Please look at the following examples from Ulysses: 


\section{A. Verb Conversion}

Verb conversion, or "dynamic" transfer, is typical of Joyce's lexical inventiveness. By his sleight of hand, not only nouns, but also some other word classes, such as adjectives "blue", "wet" and "happy", adverb "almost", and even archaic English like "thou" and "thee", can be turned into verbs. These verbs standing out from the background are effective in expressing the experiential function of language and helpful in giving a faithful presentation of persons, things and events in Dublin.

In Episode 3 "Proteus", Joyce embraces what his biographer R. Ellmann calls "the most famous of the literary devices in Ulysses," namely the "internal monologue". (p. 358) Stephen, a potential poet, is walking on the beach. Whatever he sees can trigger off his active associations. As Stephen's thoughts roll about and deconstruct themselves in quick succession in his mind, every single thing is recorded for the reader. It is very much a stream-of-consciousness technique that writers such as Virginia Woolf and Joyce himself helped refine. This following dream dialect is just one example of the internal monologue employed frequently in the novel.

Wait. Open hallway. Street of harlots. Remember. Haroun al Raschid. I am almosting it. That man led me, spoke. I was not afraid. The melon he had he held against my face. Smiled: creamfruit smell. That was the rule, said. In. Come. Red carpet spread. You will see who. (Joyce, 1996, p. 58-59)

"Almost" is so simple an adverb that an English beginner would know it, but here it could puzzle a linguist if devoid of the context. What does "almosting" mean? What does "it" refer to? At the first glance, "almosting" seems to mean "almost having sex with the prostitute" and "it" is likely to mean "the sexual affair". To solve the problem, the best way is to return to the context, to the different tenses there. Stephen's monologue here consists of two parts: the first part is from the beginning to "almosting it", written in the first-person singular and present tense; the second part is from "That man" to the end. In the second part, there is the calling voice of the pandering man before the brothel: "In. Come. Red carpet spread. You will see who." Clearly, "I am almosting it" is Stephen's present thought, which has nothing to do with the last night's dream, hence with the brothel affair. Thus, "almosting it" refers to "almost remember/recall the name of the street of harlots". Perhaps "almosting" is most typical of Joyce's idiolect. Such a lexical deviation is no less than Hopkin's famous line "the widow-making unchilding unfathering deeps", the cognitive meaning of which could be rendered as "the deeps which deprive (wives) of husbands, (children) of fathers, and (parents) of children". When you come across such a deviation, a careful reading is absolutely needed. By the way, according to Ellmann (1975, p. 49), Joyce himself had his first experience of visiting the brothel at the age of fourteen.

[Virag] is sausaged into several overcoats. (Joyce, 1996, p. 628)

Here, "sausaged", is a typical example of dynamic transfer. Virag is Bloom's dead father. One verb conversion equals several words put together: "stuffed like a sausage". With just one word, Virag's deformed appearance appears vividly in readers' mind and what's more, in a sense, such a description of the dead is necessary as a result of the whole technic of the episode: hallucination. Such wonderful examples can be found everywhere. For Joyce, words are gold. In "Sirens", some musical instruments are frequently transformed to verbs and they are both economical and impressive:

Brightly the keys, all twinkling, linked, all harpsichording... (Joyce, 1996, p. 340)

"Harpsichord" is a musical instrument, like a piano except that the strings are plucked rather than struck. Usually we say "X plays the harpsichord", but we seldom say "all (the keys) harpsichording". As we know, in a sentence which contains an object, the subject typically refers to the agent, or cause of the event, and the object refers to the person or thing which suffers the consequences of the event. Here it is obvious that Joyce's descriptive focus is not on the agent but on the object. For Joyce, it is the keys rather than the agent that produce music: those foregrounded instruments could have their own lives and could speak for themselves. It fits well with the musical theme of the episode. One more example from the same episode: "Bob Cowley's outstretched talons gripped the black deepsounding chords." (Joyce, 1996, p. 365) The strangeness of the utterance is in the way Joyce causes the action to be perceived. The pianist's hand poised above the keys becomes the talon of a bird of prey, and it grips not the keys but the chords, which are thereby turned into physical objects. A synaesthesia arises through the attribution of color, blackness, to the chords. The sentence thus produces a merger, in one impression, of three senses: touch, vision and sound.

Other examples are equally impressive, such as sirring (Joyce, 1996, p. 47), blued (p. 59), bloodying (p. 60), southing (p. 61), bagged (p. 86), to physic (p. 104), waltzing (p. 109), to out (p. 126, p. 227, dialect), to mazurka (p. 165), muttoning (p. 287), aproned (p. 155), wolfing (p. 215), wetted (p. 215), happied (p. 274), mustachioed (p. 293), tambpourined (p. 360), to up (p. 433), bassooned (p. 347), girling (p. 659), arabesquing (p. 679), Sherlockholmesing (p. 735), crookeding (p. 908), and so on. From these examples, we can see clearly that almost all the nonverb word classes can be made verbs in particular contexts. They are vivid, economical and context-bound. Of all the verb conversions, "N $\rightarrow \mathrm{V}$ " conversion is most productive and impressive, and it is especially to Joyce's liking. These "dynamic" transfers are short in form, but compact in meaning.

\section{B. Non-verb Conversion}

This type of conversion, though covering far more word classes, is less productive than the previous one. But in specific contexts, they are helpful in portraying the characters or foregrounding the theme.

Perched on high stools by the bar, hats shoved back, at the tables calling for more bread no charge, swilling, wolfing gobfuls of sloppy food, their eyes bulging, wiping wetted moustaches. (Joyce, 1996, p. 215) 
In Episode 8 "Lestrygonians", Bloom is getting hungry at 1 p.m. and looks for somewhere to lunch. He moves south and across the Liffey first to the Burton's, disgusted; then to the Byrne's pub. The eating motif is indicated in Joyce's term for the episode's technic: peristaltic - that is, peristaltic movement, the movement of food down the esophagus - and, by further extension, the entire digestive process which seems to mean that Bloom's thoughts are like the "rhythmic involuntary constrictions of the intestinal canal, whereby the contents are mixed with the digestive juices, and forced along the canal", as a dictionary defines. Joyce spends nearly two pages to describe the eating scene there, which is a microcosmic picture of Dublin and even the whole western world after the First World War as well. The above scene is what Bloom sees when he first enters Burton's. To have a better view of the restaurant, let us look at some more diners:

He gazed round the stooled and tabled eaters, tightening the wings of his nose.

That fellow ramming a knifeful of cabbage down as if his life depended on it. (Joyce, 1996, p. 215)

What a sight! All those diners are more a hungry wolf than a man! In relation to the above description, we really have much to say about so many things: those disgusting diners, Dublin's social and economic conditions, Joyce's creative technique and so on. To cut the long talk short, let us have a brief discussion of the marked conversions above, particularly the two unit nouns: gobful and knifeful. Suffix "-ful" is a grammatical marker for unit noun to stress the volume of a vessel, such as a handful of soil, a roomful of smoke, a mouthful of snow. "Gob" in plural form means "plenty of", and here "gobful" is used to suggest "an extreme amount of" or "an enormously large quantity of". "Knife" is not a unit noun itself, but here it is creatively used as a unit noun "knifeful". It is likely that Joyce coined the word following the accepted word "forkful" which means "an amount that is or can be picked up on a fork", for example, "a forkful of mutton". As is known, knife and fork are daily eating tools at the table, and it is natural that Joyce would think of using "the knifeful of cabbage" to express the great quantity. Similarly, we Chinese might have every reason to say "a chopstickful of cabbage". When having a toast meat, we do see a chopstickful of mutton of a Xin Jiang flavor, why not accept it with a smile? But here, Joyce prefers "a knifeful" to a "forkful" with an obvious ironical tone: a knife may hold less than a fork, but ill-bred men would eat from their knives. Some other conversions are easy to understand: "wolfing" is metaphorically used to mean "swallowing down food like a wolf". The whole scene is reminiscent of animals triggered by "wolfing"; both "stooled" and "tabled" refer to placement on stools and at/by the table for feeding. Farm animals are "penned", "stalled" and "stabled" for their meals. These diners are eating their food or licking the feed trough like pigs - sawdust on floor and smell of beery piss, so a bitter irony is fully conveyed. Such non-verb conversions are as vivid and descriptive as verb ones.

More examples are biscuitfully (Joyce, 1996, p. 156), cityful (p. 208), knifeful (p. 216), dongiovannism (p. 251), warningfully (p. 256), best (p. 261), eglintine (p. 267), muchly (p. 339) and so on. On the whole, conversions are laconic, vivid and expressive, which appear more in narrative sentences than in internal monologues. The possible reason is that narrators are able to control their own consciousness and allowed more free time to make good diction, but in characters' monologues, it seems that words are recorded as what they are: incorrect spellings, ungrammatical sentences, even no punctuation marks, and above all, not many conversions. But I have to point out that the so-called free flowing thought is practically not "free", it is still controlled by the conscious mind of the implicit author outside the story. So the "power of discourse" in a character's monologue is in firm control of the writer.

These conversions, though deviant, can still be accepted by common readers as the denotation and connotation of both parts of conversions are known, and combining them produces a clear hybrid: wolf + -ing (eating like a wolf); horse + ness (showing character or nature); all (every) + horse (maybe total idea of horse), etc. But this is not the end of Joyce's linguistic inventiveness. In the following section, I will see some more deviant or even "irrational" examples of word-formation.

\section{UNUSUAL COMPOUNDS}

Since compounds are vivid, descriptive and transparent, they are particularly popular with poets and writers. Joyce is one of those who feast on new compounds, and he is likely to be the only writer who carries it so far, even to the extreme. For Joyce, almost every word, whether a noun, an adjective, a verb or an adverb, can be put together to become compounds; for Joyce, compounding is more like playing a word game than doing a piece of serious scholastic work.

Ulysses presents a diversified and dazzling sight of compounds to its eager readers. According to their different syntactical roles, compounds fall into four kinds: noun compounds, verb compounds, adjective compounds and jumbled compounds. For Joyce, almost every word, whether a noun, an adjective, a verb or an adverb, can be put together to become compounds; for Joyce, compounding is more like playing a word game than doing a piece of serious scholastic work.

\section{A. Noun Compounds}

Noun compounds usually follow a $\mathrm{N}+\mathrm{N}$ pattern, with nouns usually being a common noun, but occasionally being a pronoun or even a name, such as babemaries, Hesouls, shesouls, littlejohn, Besteglinton, Bronzelydia, Minagold, Kennygiggles, Shebronze, bensoulbenjamin, and even shebeenkeeper. The very unusual kind with this type is a grammatical one: Antecedent + Relative Pron., such as Bloowho, Bloowhose and Bloohimwhom. These compounds are 
typical of a Joyce's style, although other writers may also use some portmanteau words in their works, e. g. Lewis Carroll's two well-read books: Alice's Adventures in Wonderland (1865) and Through the Looking Glass (1871). Additionally, these words are not only compact in meanings, but also rich in cultural connotations, and they are worthy of our close attention. Let us start with the grammatically unusual kind.

Filled with his god he thrones, Buddh under plantain. Gulfer of souls, engulfer. Hesouls, shesouls, shoals of souls. Engulfed with wailing creecries, whirled, whirling, they bewail. (Joyce, 1996, p. 245)

The ninth episode "Scylla and Charybdis" opens up at 2:00 p.m. in the National Library. Stephen is participating in a heated discussion mainly about Shakespeare. Stephen's erudition finds full expression in his frequent allusions to Shakespeare's biological details and Dante's The Divine Comedy and Paradise Lost, and to diverse Greek myths. Like the seas between "Scylla and Charybdis", this episode is difficult to navigate.

This short passage is full of Stephen's intertextual allusions to cultural or literary sources, such as "Yogibogeybox" (classic work of theology), "Aztec logos", "mahamahatma", "Lotus ladies", "Buddh under plantain", and above all Dante's Inferno. "Hesouls, shesouls, shoals of souls" reminds people of Dante's description of the carnal sinners in Canto 5 of the Inferno. "Hesouls" refers to those whirling men's souls and "shesouls" to those bewailing women's souls. All these lonely souls are whirled about by a "hellish storm which never rests" (Joyce, 1996, p. 35). These words are also reminiscent of the tongue twister: "She sells sea shells by the seashore."

By the Nilebank the babemaries kneel, cradle of bulrushes: a man supple in combat: stonehorned, stonebearded, heart of stone. (Joyce, 1996, p. 180)

"Babemaries" is composed of two words: babe + mary. Here the compound means "wet nurse", which is closely related to Moses' birth. The first two chapters of Exodus tell of Moses' birth. At that time, the Egyptian king gave order that all the Hebrew male babes should be drowned in the Nile. Moses was put by his own parents into a cradle of bulrushe flowing along the Nile. By chance, the princess discovered the cradle and saved him and named him "Moses". Just when the babe was found, a girl who was the babe's sister and was hidden around came along and offered a helping hand to the princess and asked the princess if she could look around and find a Hebrew babemary for the babe. The princess agreed and entrusted the babe to the care of a Hebrew woman who turned out to be his own mother. When the boy grew up, the princess adopted him as her own son. Later, the young man grew into "a man supple in combat: stonehorned, stonebearded, heart of stone." What's more, this passage is a typical example of Bakhtin's intertextuality. According to Bakhtin, our text or discourse "is filled with others' words, varying degrees of otherness and varying degrees of 'our-own-ness"”. (1986, p. 89) In other words, texts or utterances are intersected with others' words or texts, and they are inherently intertextual, constituted by elements of other texts.

Some compounds of the second type are really defamilarized and are able to lengthen readers' time of perception, for example:

Practice dwindling. A mighthavebeen. Losing heart. Gambling. (Joyce, 1996, p. 159) (V + Have + V-ed)

The above fragments are Bloom's internal monologue under the news headline "Sad" in Episode 7. In this Episode, Bloom is first seen in an office of the Freeman's Journal and National Press, and now he is in the printing works, talking about an advertisement. Inside a group of hangers-on are "professor" MacHugh, Simon Dedalus (Stephen's father), Ned Lambert, and J. J. O'Molloy. In this whole passage, Bloom does not reveal anything about the person he is worried about. Then in Bloom's monologue, whose practice is dwindling in the group? What does "A mighthavebeen" mean? From the context, we know that Bloom shows much sympathy for J. J. O'Molloy as the latter, a former lawyer, always despised by others, suffers from lung disease, goes down from bad to worse. "Practice dwindling" could be understood as "O'Molloy's business as a lawyer is wasted." For us, the bizarre compound "mighthavebeen", made up of "might + have + been", suggests an unreal condition, which can be rendered as "he might have been a successful person". This short stream reveals part of Bloom's personality: his kindness and sympathy. Bloom is always worried about other's sufferings: a quality often deprived of most people in a hypocritical self-centered society. Incidentally, "might-have-beens" is also found to mean "unrealized possibilities" in Leech and Short's vocabulary. (1981, p. 133)

Kinds of unusual words often represent the spontaneity and originality typical of mental soliloquy where Joyce's vivid linguistic imagination is working.

\section{B. Verb Compounds}

Most of the verb compounds in Ulysses function as predicates, and only a few as adverbials or subject complements. These compounds may fall into 6 kinds: V + V; Adj. + V-ed; N + V-ing; Num. + N-ed; Adj. + N-ed and Adv. + V-ing. As is known, verb group is closely related to the experiential function of language, i.e. a person's outer and inner experiences. In Ulysses, verb compounds, though small in number, are particularly important in describing the characters" "goings-on"-happening, doing, sensing, meaning, and being and becoming. Let us look at some typical examples:

The boys sixeyed father Conmee and laughed. (Joyce, 1996, p. 282) (Num. + N-ed)

As mentioned in 1.1, Episode 10 "Wandering Rocks" is a transitional episode made up of 19 separate scenes. In the first scene, Father Conmee is following a complex route: traveling by tram and on foot to the suburbs, first to the east and then to the north-east, and he meets with the Viceroy, who travels by carriage from his Lodge in Phoenix Park roughly east to open a charity bazaar. At the corner of Mountjoy square, Father Conmee stopped three little schoolboys from Belvedere where Joyce himself once attended: Jack Sohan, Gallaher and Brunny Lynam. "Father Conmee gave a 
letter from his breast to master Brunny Lynam and pointed to the red pillarbox at the corner of Fizgibbon street" and he joked: “- But mind you don't post yourself into the box, little man, he said." Having heard these amusing words, "The boys sixeyed father Conmee and laughed." (Joyce, 1996, p. 282) Obviously, "sixeyed" can be rendered as "the six eyes stared wide at". Here, just one verb compound equals six words without loss of its meaning. Moreover, the compound is packed with more than its cognitive meaning: a stylistic coloring in the context. A vivid picture of those three lovely boys is instantly aroused in the reader's mind, and meanwhile, Father Conmee's kindness and charity are strongly felt. To the reader, "sixeyed" is as funny and humorous as Father Conmee's joke.

He seehears lipspeech. (Joyce, 1996, p. 365)

This is a typical SVO sentence. But what's unusual in this short statement is its two compounds: a verb one and a noun one. To fully understand the sentence, we need to have a look at its context. As we know, Bloom had a miserable time at the Ormond bar. He tried every means to kill the time, but he failed. When the barreltone Ben Dollard was requested of singing The Croppy Boy in "F sharp major", Bloom hesitated a lot about the question of staying or not.

Must go prince Bloom told Richie prince. No, Richie said. Yes, must. Got money somewhere. He's on for a razzle backache spree. Much? He seehears lipspeech. One and nine. Penny for yourself. Here. Give him twopence tip. Deaf, bothered. But perhaps he has wife and family waiting, waiting Patty come home. Hee hee hee hee. Deaf wait while they wait. (Joyce, 1996, p. 365)

From the dialogue, we know that "he" refers to Richie. What's Richie's talking style? While listening to the waiter, Richie always watches the other's lips.

This is the cleverest use of verb collocation. Our common sense tells us that we "see lips", but "hear speech". But it is often the case that we may use our different senses at the same time. For example, when we walk in the street, we see people and things with our eyes, and meanwhile we hear voices with our ears. Usually we need to describe them with different sentences, but possibly for Joyce, this is too chatty and troublesome. His verb compound "seehears" speaks for itself. "seehears" is laconic and impressive, suggesting well the immediacy and simultaneity of the two actions. More examples:

He smellsipped the cordial juice and, bidding his throat strongly to speed it, set his wineglass delicately down. (Joyce, 1996, p. 220)

Davy Byrne smiledyawnednodded all in one:

-Iiiiiichaaaaaaach! (Joyce, 1996, p. 226)

At Davy Byrne's, Bloom sees “Moral people. He doesn't chat.” Bloom greets Nosey Flynn at the corner of the bar, then orders a cheese sandwich and a glass of burgundy which proves to be the cause of Bloom's farting at the end of Episode 11. Nosey Flynn upsets Bloom a lot when the other is picking up the embarrassing topic of Boylan's coming tour. After drinking the wine, Bloom's midriff "yearned then upward, sank within him, yearned more longly, longingly". (p. 220). Bloom sees Flynn first smelling his juice and then sipping a bit, so Flynn "smellsipped the cordial juice and, bidding his throat strongly to speed it, set his wineglass delicately down." Later, the bar holder Davy Byrne comes along and has a very long chat with Nosey Flynn. Still later, Nosey Flynn does most of the talking and occasionally Davy Byrne puts in a few words or asks a simple question. At this moment, Davy Byrne "smiledyawnednodded". This compound is made of three verbs: smiled + yawned + nodded, suggesting the immediacy and simultaneity of the three actions. In addition, in this specific context, it may serve as a hint to the talkative Nosey Flynn that "I'm tired or drowsy. Let's wind up the gossip." At another time, Joyce used three "ands" to express those simultaneous actions: "Father Conmee smiled and nodded and smiled and walked along Mountjoy square east." (p. 282)

So much for Joyce's creative use of verb compounds. Joyce's creative use of language is well displayed in other kinds of compounds.

\section{Adjective Compounds}

Compounds of this type are largely derived from present or past participles. The main difference between adjective and verb compounds lies not in their formations but their syntactical functions. The former perform the role of an adjective and the latter that of a predicate. Adjective compounds are well used in the novel for brevity and vividness. Here are some typical examples:

...welshcombed his hair with raking fingers. (Joyce, 1996, p. 160)

"welshcombed" is formed by a noun plus -ed. The sentence describes Mr Dedalus's way of combing his hair: he combed his hair with raking fingers like Welsh people. In addition to the lexical meaning, this compound also carries some cultural implication. A "welsh comb" is the thumb and four fingers because the Welsh were popularly regarded as a wild and unkempt people. (Gifford and Seidman, 1988, p. 135) An ironical tone is conveyed here, and meanwhile, the minute description of a minor character allows Joyce a faithful representation of everything in Dublin.

Paris: the wellpleased pleaser (Joyce, 1996, p. 245)

Similarly, besides the well-used lexical meaning of "feeling or showing great satisfaction or happiness", the compound is loaded with cultural implications. "Paris" here is a pun. As we know, Paris is the capital of France and one of the most attractive cities in the world; meanwhile, Paris is the son of King Puliomos with whom Hera eloped in Greek mythology. The pun turns on the Greek myth of Paris, who pleased Aphrodite, the goddess of love, by awarding her the prize in a beauty contest with Athena and Hera. Aphrodite in turn pleased Paris by awarding him Helen of Troy. "Paris" here refers to Shakespeare. (Gifford and Seidman, 1988, p. 210) Then one more example: 
Both then were silent?

Silent, each contemplating the other in both mirrors of the reciprocal flesh of theirhisnothis fellow faces. (Joyce, 1996, p. 824)

Episode 17 is the most beautiful episode of the book, though at first sight it is the most forbidding. It was said to be Joyce's favorite episode and Joyce called it the "ugly duckling of the book". (Budgen, 1972) The story happens at about 2 a.m. the following morning. Stephen accepts Bloom's invitation to his home for a cup of "cocoa". (Joyce, 1996, p. 790) On arrival, Bloom finds that he has forgotten his key, so jumps down into the basement well and comes up to the front door to let Stephen in. He lights a fire and boils a kettle, and they drink cocoa. They discuss the Hebrew and the Irish languages. Later Bloom invites his guest to stay for the night, but Stephen amicably declines. They go out into the yard and urinate, looking up at the stars and at Molly's lighted bedroom window. Stephen walks off into the night and Bloom goes upstairs to bed. The unusual compound "theirhisnothis" implies one major theme of the novel-the symbolic meeting of the spiritual father (Bloom) and the son (Stephen). "Theirhisnothis" can be broken into four words: their + his + not + his. From the compound itself and its specific context, we may infer some important implication. After a painstaking quest for paternity, both Bloom and Stephen have finally satisfied their needs of meeting each other, each discovering spiritual comfort from the other, which is sure to mark a turning point in their own lives and which is absolutely necessary and important in a spiritual "wasteland" of Dublin. After their meeting, Stephen declines to stay the night and probably will not see Bloom again. Yet the narrative manages to convey their union as symbolically meaningful. In some other places, there are sufficient linguistic features to suggest their union in terms of their mutual interest, sensation, knowledge, viewpoint, and so on. "Most of the points on which the two men make contact are comically trivial; some, like the relation between their ages or educations, are ludicrous. Nevertheless, twice when each sees in the other glimmerings of meaning, and once when each feels a communion with the other's flesh-they are able to transcend the difference between their intellects, experiences, and ages, and the similarity of their gender.... However, these moments of communion between such different people, when seen in the context of all we know of Dublin, and the thick texture of correspondence and analogy that surrounds the events of this day, have a significance that transcends the personal." (French, 1982, p. 231) "The communion, incomplete as all human contact is doomed to be, and only obscurely perceived, symbolizes the fellow feeling of all mankind, a recognition, however tenuous, of the vulnerability and similarity of all people who suffer from the indifference of the stars and impulses of the flesh, all caught in one universal pattern of experience, the human condition, made up of necessity, on the one hand, and incertitude ${ }^{1}$, on the other." (ibid, p. 232)

Episode 15 "Circe" is full of compounds. In my reading, I find some 810 compounds of various kinds. Time permitting, a more careful study would be significant.

\section{Jumbled Compounds}

Tentatively, I shall classify them into two kinds: lexical and non-lexical. The former refers to those jumbled compounds whose meanings can be recognized according to their separate elements, such as contransmaginificandjewbangtantiality, greatgrandfather, awfullygladaseeragain, Junejulyaugseptember, stickumbrelladustcoat, Rutlandbaconsouthamptonshakespeare, Dunducketymud-coloured and even handsomemarriedwomanrubbedagainstwide- behindinClonskeatram; the latter refers to the non-lexical (or super-lexical) compounds which carry more emotional meanings than lexical ones, whose meanings cannot be arrived at according to their separate elements, such as wayawayawayawayawayaway, doggy-bowwowsywowsy, greaseaseabloom, endlessnessnessness, wavyavyeavyheavyeavyevyevy, Helterskelterpelterwelter, Weeshwashtkiss- imapooisthnapoohuck, etc. The difficulty with both types is their stylistic values or rich cultural connotations. Let us start with the lexical compounds. Please look at the following example from Episode 3:

When Rutlandbaconsouthamptonshakespeare or another poet of the same name in the comedy of errors wrote Hamlet he was not the father of his own son.... (Joyce, 1996, p. 267)

This 34-letter compound consists of two persons' names: Bacon and Shakespeare, and two places' names: Rutland and Southampton. What's the mystery of these names? For long, as we know, there have been countless rumors about the authorship of Shakespeare's plays. Here is one of the sayings that there are three leading candidates for the role of Shakespeare's ghostwriter and they are Roger Manners (1576-1612), fifth earl of Rutland, Sir Francis Bacon (1561-1626) and Henry Wriothesly (1573-1624), third earl of Southampton. Some scholars, such as Delia Bacon (1811-1859) and Appleton Morgan (1846-1928), have remained unconvinced that Shakespeare had ever authored the plays. Delia Bacon suspected that in addition to Bacon, Raleigh and others were in on the deception, and Appleton Morgan, the New York City lawyer, believed a consortium of noblemen, including Southampton, Raleigh, Essex, Rutland, and Montgomery wrote the plays and used that prompt-book "copyist" Shakespeare as front man. There is much argument about the authorship of Shakespeare's plays. Positive argument in favor of the theory that Bacon wrote Shakespeare, hinges on juxtaposing "passages of similar import" from the two writers, while negative argument in favor of the theory maintains that Shakespeare's plays must have been written by a man more knowledgeable than

\footnotetext{
1 French (1982) argues that Joyce clearly intended to show incertitude as operating in the cosmos as well as the world. In "Ithaca" episode, such expressions as "No fixed stars / variable suns", "parallax aberration of light", "deal logically with unknown", etc. are good examples to reveal the idea of incertitude. See more in Herring's Notesheets, 1972: 454-455.
} 
Shakespeare, with his background, could have been. Possibly, similar arguments will never disappear and the authorship of Shakespeare's plays will remain an eternal mystery, but what's more important for us to do, is try to recognize the cultural and literary importance of Shakespeare's works as much as possible (see especially Gifford and Seidman, 1988, p. 219-220, p. 241-242).

...John Wyse Nolan, handsomemarriedwomanrubbedagainstwidebehind-

inClonskeatram, the bookseller of Sweets of Sin, Miss Dubedatandshedidbedad.... (Joyce, 1996, p. 686)

These two odd compounds appear in the long stage direction of Episode 15 "Circe" where both Bloom and Stephen's hallucinations are dramatized. At a brothel in the red-light district of Dublin, the reader is presented with horrible scenes of street urchin and deformed children, rowdy British soldiers and depraved prostitutes. All the time Bloom seeks to protect the young man from being swindled and Stephen continues his own descent into drunken madness. The farce continues when Bloom's bar of lemon soap begins to speak and Mrs. Breen, the wife of the lunatic Denis, appears in the road and flirts with Bloom before mocking him for getting caught in the red-light district. Bloom is suddenly in a courtroom, charged with accusations of lechery. Several young girls recount sordid stories of Bloom, the conspicuous voyeur, and the courtroom's roll includes various characters from earlier in the day including Paddy Dignam and Father Coffey, who presided over Dignam's funeral. The narrative abruptly shifts when Bloom finally arrives at Bella Cohen's brothel. The masochist tint of Cohen's brothel emphasizes female domination, lust, gluttony and the bestial nature of man. Bella's enchantress-like function is reaffirmed in the copious pig and bondage imagery of the "Circe" episode. While the ancient Ulysses overpowered Circe, Bloom immediately succumbs to hallucinations. In his major sexual hallucination, Bloom enjoys the transformation of "Bella" to "Bello" as he is "transformed" into a feminized beast. The brothel functions as a sty and both the prostitutes and their patrons are chained to sordidness of Nighttown at the same time that they each suffer under the burdens of memory.

The first example consists of 10 words and 57 letters. In fact, this coinage is really not a woman's name but a brief description of the woman's characteristics. Then how about this woman? She is handsome + married + woman + rubbed + against + wide + behind $+i n+$ Clonskea + tram. Let us start with Clonskea. At the opening lines of Episode 7 "Aeolus", under the headline of "In The Heart Of The Hibernian Metropolis", it reads "Before Belson's pillar trams slowed, shunted, changed trolley, started for Blackrock, Kingstown and Dalkey, Clonskea, Rathgar and Terenure ...." (Joyce, 1996, p. 147) Obviously, Clonskea is a name of a place or a tram stop and there is a tram going there. By chance, at Episode 10 "the Wandering Rocks", we see Father Conmee get on a tram: "At Newcomen Bridge Father Conmee stepped into an outward bound for he disliked to traverse on foot the dingy way past Mud Island.” (10: 284). At the tram, "Father Conmee perceived her perfume in the car. He perceived also that the awkward man at the other side of her was sitting on the edge of the seat." (ibid, p. 285) All these things are in the control of the ubiquitous narrator. It is funny to realize the fact that the so-called powerful narrator is somewhat forgetful and now he cannot remember the rich woman's name! In Episode 15, the narrator also forgets quite a lot of names including that of the woman with "perfume". So the narrator is only a restricted one who knows not the whole facts but just a bit more than the reader. With this information in mind, we may interpret the eccentric compound as "that perfumed woman who had been on the same tram for Clonskea with Father Conmee was handsomely married, and her huge body and sexual hips rubbed against the man's and made the man passenger rather awkward." With a funny anecdote, the nonce word is contributive not only to the internal cohesion and coherence of the whole text, but also to achieving the comic effect of the work.

"Dubedatandshedidbedad" is another imaginative nonce word. It can be broken into two meaningful parts: "Dubedat", a girl's name and a sentence "and + she + did + bedad". There is also a funny story behind it. In Episode 8 "Lestrygonians", Bloom is dining at Davy Byrne's pub. He tries to "eat" his sorrows while listening to the tedious chat between Nosey Flynn and Davy Byrne, the pub keeper. Rushing into his "screen of consciousness" is a flowing of his past events: his dead son Rudy 10 years ago, his suicide father, those flirtatious women, and above all his past sweet memories with Molly.

A typical feature of the vocabulary in the interior monologue, and also of Joyce's language in general, is the use of onomatopoeic words mentioned in 2.2, which characterizes a spontaneous, primitive linguistic invention in the soliloquist's mind. In our familiar Episode 11, there are two interesting super-lexical oddities:

It soared, a bird, it held its flight, a swift pure cry... all soaring all around about the all, the endlessnessnessness.... (Joyce, 1996, p. 355)

Her wavyavyeavyheavyeavyevyevy hair un com: 'd. (Joyce, 1996, p. 358)

At the middle of Episode 11, when Simon Dedalus finishes "Martha", everyone in the bar is almost struck dumb as it is "soaring high, high resplendent, aflame, crowned, high in the effulgence symbolistic, high, of the ethereal bosom, high, of the high vast irradiation everywhere". "Endlessnessnessness" seems that every sound has its special individual value and every syllable its particular significance. Reinforced by the three repetitions of the suffix "-ness" in the compound is the special effect of the music lingering around the beams. In this specific context, the lingering sound has aroused Bloom's close emotional communion.

The compound "wavyavyeavyheavyeavyevyevy" is ripplingly "wavy" (and perhaps heavy and weavy) like Molly's hair, which carries some special contextual implications: (1) A rhythmic patterning is made by the combination of the mimic adjective "wavy" with a series of units which resemble it. The particularly aural appeal of Joyce's language has often been emphasized but in this example the visual effect is predominant; (2) The short passage reveals how much 
Bloom cares about Molly. At the moment, Molly once again steals into Bloom's stream: "They sing. Forgotten. I too. And one day she with. Leave her: get tired. Suffer then. Snivel. Big Spanishy eyes goggling at nothing." (Joyce, 1996, p. 358) Bloom even imagines the miserable sight of Molly being betrayed and deserted by Boylan one day when she becomes no longer sexy and attractive with age. He is caught in a conflicting emotional predicament: on the one hand, Bloom feels distressed for Molly's possible suffering future; on the other, he feels enraged both at Molly's ignorance and at Boylan's frivolous deeds. To give vent to his anger, Bloom uses this bizarre compound. This transference of characteristics from the object to the word is similar to onomatopoeia, but in this case the quality so transferred is a physical one (waviness, endlessness) rather than an acoustic one.

MARION'S VOICE: (Hoarsely, sweetly rising to her throat) O!

Weeshwashtkissimapooisthnapoohuck! (Joyce, 1996, p. 671)

THE HUE AND CRY: (Helterskelterpelterwelter) He’s Bloom! (Joyce, 1996, p. 686)

In Episode 15, Bloom seems to be in an inferno, crisscrossed by hundreds of characters, objects and ghosts. In the hallucinations, dozens of persons, things or animals, living or dead, could rise against Bloom and punish him in a way, such as the calls, the answers, the urchins, the bells, the gong, a voice, bridge, the wreaths, first watch, the gulls, longhand and short hand, Dlugacz, the sluts and ragamuffins, the timepiece, the quoits, the nameless one, the recorder, the kisses, the chimes, a dead hand, Brother Buzz, the fan, the yews, Alexander Keyes, the waterfall, the dummymummy, hours, the pianola, the hue and cry, the bracelets, the horse, the hound, and even Bloom's late father Virag, his dead son Rudy, Paddy Dignam (dead), Mesias, the Nymph, the Croppy Boy, Edward VII as well as Shakespeare. The personifications of both "the hue and cry", "Marion's voice" and many absurd voices were the focuses of the "surreal play", and preyed on Bloom by interrogating him in turn, fully demonstrating the chaotic and preposterous nature of Dublin's society. The stage direction "Helterskelterpelterwelter" may be broken into three parts: helter-skelter + pelter + welter. Helter-skelter: every which way; pelt/pelter: v. to throw at; welt: n. a bruise. The last two may just be added, but in the context may be meaningful. The compound is to describe the noisy, chaotic and panicky state of "the hue and cry". If we can make some sense of the compound above, we can feel quite helpless about "weeshwashtkissimapooisthnapoohuck". It is more a string of sounds than a meaningful compound, and it is really like Shakespeare's "ventriloquy" (Joyce, 1996, p. 671) which is supposed to be known by no one else but Joyce himself. When doing the translation, we seem to have no way out but to adopt a technique of transliteration. There is a superfluous use of such nonlexical compounds.

By rendering those sounds of animals and things, Joyce is keen on adopting the skill of "ventriloquy" to present a lifelike imitation of those sounds. The following is the longest and most eccentric example in the novel and possibly in the English language:

...Nationalgymnasiummuseumsanatoriumandsuspensoriumsordinaryprivatdocentgeneralhistoryspecialprofessordoct or Kriegfried Ueberallgemein. (Joyce, 1996, p. 397-398)

Kriegfried Ueberallgemein is one of "the picturesque foreign delegation known as the Friends of the Emerald Isle" I mentioned at the beginning of this section. The first sight of this monster-like word would send shudders to our backbones. We would be all keyed up about the butt of Joyce's attacks. Used to describe the distinguished professor is a grotesque compound, composed of 105 letters and 13 words. Obviously, satirical effects are supercharged by pilings up of so many titles. This compound is typical of Joyce's linguistic inventiveness or originality which truly achieves its special artistic effect of "defamilarization" by shocking its readers into new awareness of both the nonce word and the man being modified.

But on the other hand, some of Joyce's compounds here and in other places break the rules of the language so markedly that they seem to go to the extremes. Suspicions may easily arise: is it necessary for Joyce to complicate an easy matter? For us, it is true that sometimes Joyce goes beyond those possibilities of the linguistic creativity, so while reading Ulysses, we need to take those nonce words critically, that is, we cannot accept them blindly as a few neologisms like "muchly" and "crookeding" (18: 908), are not so cleverly made.

\section{Perfect Language was Perfect Truth}

The above examples fully illustrate Joyce's unsurpassed power of lexical creativity. But this is by no means the goal of Joyce's linguistic experimentation. It is no exaggeration to say that $F W$ is notorious for its bizarre word-blends and neologisms. In fact, Joyce's blends are not words of English language at all, but grotesque and often amusing formations created by the distortion and mingling of English or foreign words. Scattered in the novel, these various kinds of conversion, compound, and word-play seem to be made of Joyce's free will and are likely to be neglected by careless readers or beginners; brought together by classification and contrast, they will speak for themselves: they are made by Joyce's careful design and most of them are even rule-governed. "Joyce's style is distinguished not only by the rise and fall of its rhythms, but by its feeling for the texture of the particular word. Words assert a magical power over things. Treasured phrases enable Stephen to transform 'the dull phenomenon of Dublin' to transcend 'the decayed city' by communing with a rapturous seascape.” (Levin, 1941) By sleight of Joyce's hand, words do "assert a magical power over things" and carry lives of their own both in narrative sentences and internal monologues. By constantly employing unusual neologisms in interior monologues, Joyce meant to recreate or record series of associations in the word order in which they developed at the moment when those words came to mind. For Joyce, it seems that to reproduce a rapid flow 
of associations at the prespeech level of consciousness, the traditional resources of the English language as such are not sufficient, so it is natural for him to make the best use of "poetic license" of the literary language and to make as many neologisms as he hoped. By so doing, Joyce succeeded not only in recording those series of association and thought, but also in increasing the expressive power of English, the literary language in particular. Perfect truth seems to be Joyce's first policy in his lexical inventiveness. Whether Joyce's standard utterances, nuances of language or defamiliarized lexis, they seem to point at the same way: "language and reality are one. Perfect truth was perfect language." (French, 1982).

\section{CONCLUSION}

The lexical defamiliarization or inventiveness in Ulysses is explored in the following two kinds: verb conversion and compounds. Verb conversion, also called dynamic transfer, is classified into verb conversion and non-verb conversion. By Joyce's sleight of hand, not only nouns, but also some other word classes, such adjectives as "blue", "wet" and "happy", adverb "almost", and even archaic English words like "thou" and "thee", can be equally turned into verbs. Non-verb conversion, though covering far more word classes, is less productive, but equally fresh, vivid and expressive. These conversions, short in form but compact in meaning, are lively, economical and impressive, and in some specific contexts they are effective in expressing the experiential function of language and helpful in giving a faithful presentation of persons, things and events in Dublin.

To sum up, we may come to the following four conclusions. (1) Joyce's defamiliarized lexis is more motivated than arbitrary as he made the best use of the accepted lexical resources; (2) As for various word formations, we find that Joyce's verb conversion follows fairly well the word-formation rules, his compounds deviate a lot from the rules and his jumbled compounds are, in its true sense, what Bakhtin calls "linguistic carnivalization"; (3) Semantically, neologisms, though fleeting, are terse, lively, exciting, expressive, and above all true to life. (4) Perfect truth was perfect language." (French, 1982). The point with his linguistic inventiveness is to make full use of the visual and auditory textures of words, including their musical nature, and to increase the expressive power of literary language, and thus to achieve the special artistic effects of "defamiliarization" by increasing the difficulty of reading and lengthening their time of perception, and it is in grappling with linguistic deviation, creativity and indeterminateness that lies much of the pleasure of reading Ulysses. So Joyce's linguistic inventiveness is part of his artistic ingenuity in fiction and calls for further studies.

\section{REFERENCES}

[1] Bakhtin, M. M. (1986). Speech genre and other late essays. In C. Emerson \& M. Holquist (eds), trans. W. McGee. Austin: University of Texas Press.

[2] Budgen, F. (1934 / 1972). James Joyce and the making of "Ulysses". New York: Harrison Smith \& Robert Haas.

[3] Ellmann, R. (1975). Selected letters of James Joyce. London: Faber \& Faber.

[4] Fowler, R. (1996). Linguistic criticism. Oxford: Oxford University Press.

[5] French, M. (1982). The book as world. London: Sphere Books Ltd.

[6] Gifford, D. \& R. J. Seidman (1988). Ulysses annotated. Berkeley: University of California Press.

[7] Joyce, J. Ulysses. (1996). New York: Random House, 1934, $2^{\text {nd }}$ printing, with a foreword by Morris L. Ernst and the decision of the U.S. District Court rendered by Judge John M. Woolsey; reprinted, Nanjing: Yinlin Press.

[8] Joyce, J. Ulysses. (1996). trans. by Xiao Qian and Wen Jieruo, published by Yilin Press.

[9] Leech, G. N. (2001). A linguistic guide to English poetry. Peking: Foreign Language Teaching and Research Press.

[10] Levin, H. (1941). James Joyce: A critical introduction. New York: New Directions.

[11] Mukarovsky, J. (1964). Standard language and poetic language. In P. L. Garvin (ed), A Prague school reader on esthetics, literary structure and style. Washington: Georgetown University Press.

[12] Shklovskij, V. (1917/1965). Art as technique. In L. T. Lemon \& M. J. Reis (eds), Russian formalist criticism. Lincoln: University of Nebraska Press.

[13] van Peer. (1986). Foregrounding and psychology. London \& Sydney: Croom Helm.

Xianyou Wu, born in 1965, Sichuan province, China, is currently a professor of English at School of Foreign Languages and Literature, Chongqing Normal University, China, and also Head of the School. He earned his Ph. D in English Language and Literature from Henan University, China, in 2005. His research interests cover such areas as literary stylistics, systemic-functional linguistics and Joyce studies. He published his monograph Foregrounded Linguistic Features in Ulysses: A Stylistic Way of Reading (Peking, China Central Documents Press, 2006) and some 40 articles in Chinese academic journals. 